\title{
Genomic view of the evolution of the complement system
}

\author{
Masaru Nonaka • Ayuko Kimura
}

Received: 15 June 2006 / Accepted: 19 June 2006 / Published online: 9 August 2006

(C) Springer-Verlag 2006

\begin{abstract}
The recent accumulation of genomic information of many representative animals has made it possible to trace the evolution of the complement system based on the presence or absence of each complement gene in the analyzed genomes. Genome information from a few mammals, chicken, clawed frog, a few bony fish, sea squirt, fruit fly, nematoda and sea anemone indicate that bony fish and higher vertebrates share practically the same set of complement genes. This suggests that most of the gene duplications that played an essential role in establishing the mammalian complement system had occurred by the time of the teleost/mammalian divergence around 500 million years ago (MYA). Members of most complement gene families are also present in ascidians, although they do not show a one-to-one correspondence to their counterparts in higher vertebrates, indicating that the gene duplications of each gene family occurred independently in vertebrates and ascidians. The $\mathrm{C} 3$ and factor B genes, but probably not the other complement genes, are present in the genome of the cnidaria and some protostomes, indicating that the origin of the central part of the complement system was established more than 1,000 MYA.
\end{abstract}

Keywords Complement $\cdot$ Genomic $\cdot$ Evolution

M. Nonaka $(\bowtie) \cdot$ A. Kimura

Department of Biological Sciences, Graduate School of Science, The University of Tokyo,

7-3-1 Hongo,

Bunkyo-ku, Tokyo 113-0033, Japan

e-mail: mnonaka@biol.s.u-tokyo.ac.jp

\section{Introduction}

Adaptive immunity in which the lymphocyte receptors and the major histocompatibility complex (MHC) molecules play a central role in the recognition of foreign molecules, is specific to the jawed vertebrates, suggesting that its evolutionary origin was around 600 million years ago (MYA) (Flajnik and Kasahara 2001). The origin of innate immunity is believed to be even more ancient, although innate immunity is composed of many heterogeneous systems and in most cases their evolutionary origins are poorly defined. The complement system, one of the most sophisticated innate immune systems of mammals (Volanakis 1998; Walport 2001a,b), was studied intensively from an evolutionary viewpoint because researchers are keen to know how such a sophisticated biological reaction system was established. More than 30 years ago, phylogenetic studies of the complement system were performed, mainly using hemolytic activity in body fluids as the criterion for the presence of the complement system. These studies identified complement-like hemolytic activities, not only from various vertebrates but also from invertebrates (Gigli and Austen 1971). The intrinsic problem with this approach, however, was that it was difficult to discriminate hemolytic activity due to the complement system from hemolytic activities due to other factors. For example, the complement-like activity once reported from arthropod hemolymph, which can be rendered hemolytic after activation by cobra venom factor (Day et al. 1970), turned out to be lecithin that was converted to lysolecithin by phospholipase A present in the cobra venom factor preparations (Hall et al. 1972). Phylogenetic studies of the complement system were then performed mainly at the protein level (Nonaka et al. 1981), leading to identification of complement components from most classes of verte- 
brates, including agnatha (Nonaka et al. 1984). At that time, it was generally believed that the complement system was a unique property of the vertebrates because all attempts to identify complement components from invertebrates had failed. Over the past 10 years, DNA-level analysis, including genome analysis and EST analysis, has significantly extended our knowledge about the evolutionary origin of the complement system. The initial phase of DNA level analysis revealed the presence of the complement genes in invertebrate deuterostomes such as sea urchins (Al-Sharif et al. 1998) and ascidians (Ji et al. 1997). In contrast, no complement gene was found in the genomes of Drosophila melanogaster (Adams et al. 2000) or Caenorhabditis elegans (The C. elegans Sequencing Consortium 1998), suggesting that the complement system was established in the deuterostome lineage. However, recent reports on the horseshoe crab C3, factor B (Bf) (Zhu et al. 2005), and coral C3 (Dishaw et al. 2005) and a sea anemone genome analysis indicate that the complement system is of a much more ancient origin. In this review, we examine a current assessment of the evolution of the complement system revealed mainly by the genome and by other DNAlevel analyses.

\section{Phylogeny of animals}

As molecular research proceeds, the evolutionary origin of the complement system was revealed to be increasingly ancient. Hence, it is necessary to understand a wider range of animal phylogeny to follow the evolutionary process of the complement system. The current view of animal phylogeny and estimated divergence times among major animal groups based on the recent molecular clock analyses (Blair and Hedges 2005a,b; Hedges et al. 2004) is summarized in Fig. 1. As shown in this figure, molecular data suggest that eumetazoa diverged into Cnidaria and Bilateralia about 1,300 MYA. At approximately 1,000 MYA, Bilateralia then diverged into Deuterostomia and Protostomia, and the latter diverged further into Ecdysozoa and Lophotrochozoa. In the Deuterostomia lineage, Chordata diverged from Echinodermata/Hemichordata around 900 MYA. Among three Chordata subphyla, Cephalochordata first diverged 890 MYA, and Urochordata and Vertebrata diverged 790 MYA. From the main Vertebrata lineage, Cyclostomata diverged 650 MYA and Chondrichthyes diverged 530 MYA. This phylogenetic tree, however, is still not conclusive; a recent report has suggested a close relationship between Cephalochordata and Echinodermata (Delsuc et al. 2006). The adaptive immunity based on lymphocytes and $\mathrm{MHC}$ is present in Chondrichthyes and other jawed vertebrates, but not in Cyclostomata. Thus, adaptive immunity most probably appeared between 530 and 650 MYA.

\section{Presence and absence of the complement genes in various animal genomes}

To trace the evolution of the complement system, we searched the genome data of chicken (Gallus gallus, http:// www.ncbi.nlm.nih.gov/genome/guide/chicken/), clawed frog (Xenopus tropicalis, http://genome.jgi-psf.org/Xentr4/ Xentr4.home.html), pufferfish (Takifugu rubripes, http:// genome.jgi-psf.org/Takru4/Takru4.home.html), and sea anemone (Nematostella vectensis, http:/www.stellabase. org/) for the presence of the complement genes. Because five complement gene families, $\mathrm{C} 3 / \mathrm{C} 4 / \mathrm{C} 5, \mathrm{Bf} / \mathrm{C} 2, \mathrm{MASP} /$ $\mathrm{C} 1 \mathrm{r} / \mathrm{s}, \mathrm{C} 6 / \mathrm{C} 7 / \mathrm{C} 8 \mathrm{~A} / \mathrm{C} 8 \mathrm{~B} / \mathrm{C} 9$, and Factor I (I), have a unique domain combination found only among complement genes in the human genome, identification was carried out based merely on the predicted domain structures. For other complement genes, however, the same domain combination is also found in noncomplement genes. In these cases, phylogenetic tree analysis was performed to confirm the orthologous relationship between the possible complement genes of various animals and their mammalian counterparts. Figure 2 summarizes the current status of the presence/absence of the complement genes judged by these searches, the published results, and our unpublished experimental data.

Mammals, Aves, Amphibia, and Teleostei seem to have the full set of complement genes except for factor D and the regulators of complement activation (RCAs) family members and additional sporadic absences such as chicken $\mathrm{C} 2$ and $\mathrm{C}$, properdin, amphibian $\mathrm{C} 1$ inhibitor, and teleost MASP-1 and MASP-3. Although these sporadic absences are most probably due to secondary loss in each animal lineage, the absence of factor $\mathrm{D}$ and $\mathrm{RCA}$ may reflect technical problems in identifying them. Factor D has only a serine protease domain (Volanakis and Arlaud 1998), and its domain structure seems to be too simple to be used for identification. Thus, it is possible that the $\mathrm{D}$ gene is present in the chicken and clawed frog genomes, but is overlooked by present analysis. Similarly, all RCA members have a simple domain structure composed of repeats of a single domain termed short consensus repeat (SCR) (Hourcade et al. 1989). Because the primary structures of the RCA member SCRs are poorly conserved even among mammalian species and many noncomplement genes are also composed of SCRs, it is difficult to identify the RCA genes on the basis of their domain structure. Therefore, it is highly probable that these genes are present but not identifiable in some animal genomes. Thus, most of the gene duplications that played a significant role in establishing the modern complement system of higher vertebrates seem to have occurred before the divergence of teleosts and tetrapods, which is estimated to have been about 500 MYA. 


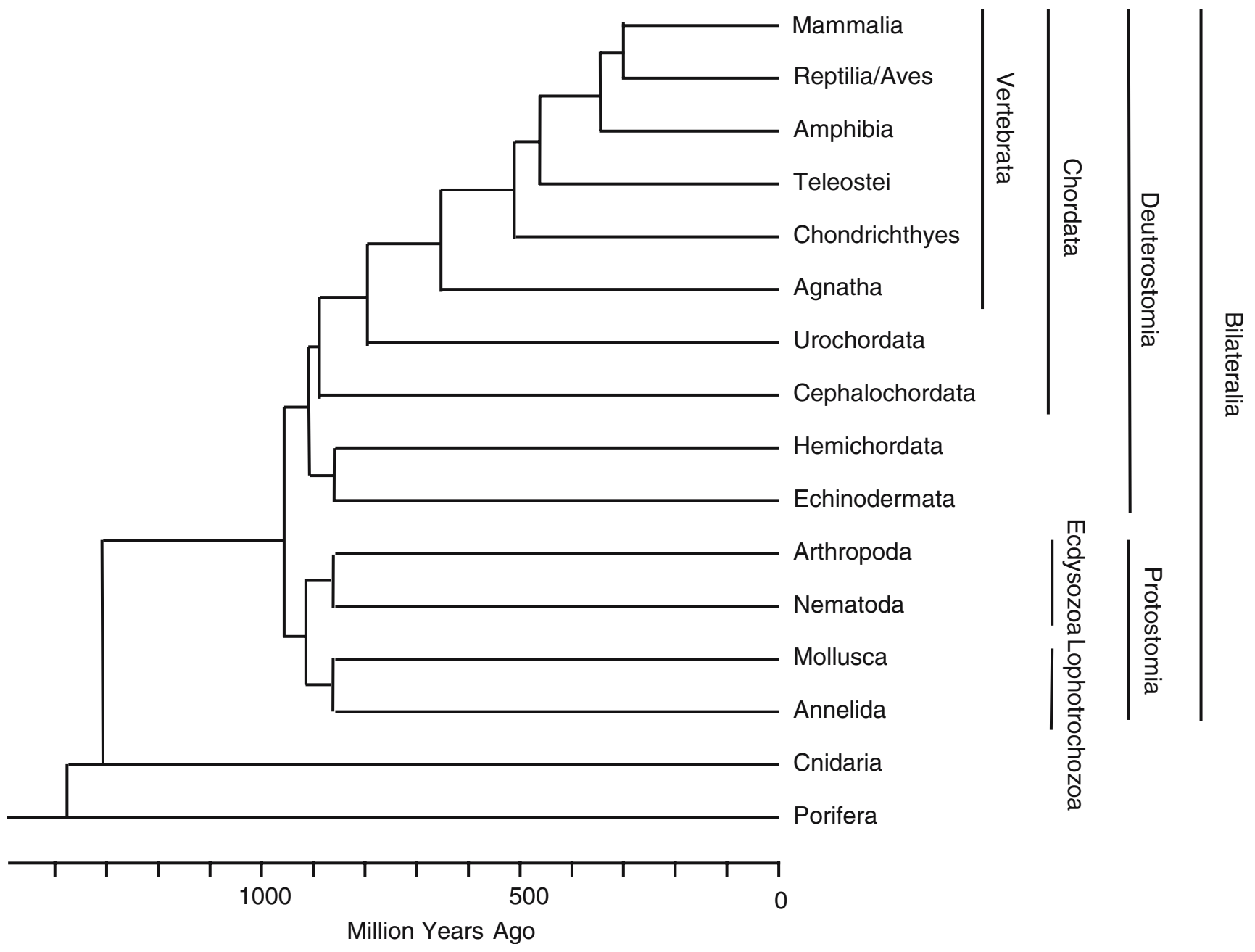

Fig. 1 Phylogenetic relationship among animals. Phylogenetic relationship among multicellular animals elucidated by molecular clock methods based on protein sequence data is shown. Only animal groups

The lack of genome-wide information in Chondrichthyes and Agnatha makes it difficult to evaluate the evolutionary stage of their complement systems. However, earlier functional analysis of the shark and lamprey complement systems indicated that the former possesses hemolytic activity, while the latter lacks it (Jensen et al. 1981; Nonaka et al. 1984). Later reports on their individual complement component genes supported the idea that the complement system of Chondrichthyes may be similar to that of higher vertebrates, whereas the complement system of Agnatha shows some crucial differences from it. Thus, the $\mathrm{C} 3 / \mathrm{C} 4 / \mathrm{C} 5$ and $\mathrm{Bf} / \mathrm{C} 2$ gene duplications seem to have occurred in the jawed vertebrate lineage after the divergence of Agnatha. Moreover, not only gene duplications among C6, C7, C8A, $\mathrm{C} 8 \mathrm{~B}$, and $\mathrm{C} 9$ but also the presence of any of them were not identified in Agnatha (A. Kimura and M. Nonaka, unpublished data). Therefore, the vertebrate complement system seems to have experienced a drastic change after the relevant to this review are included. The divergence times for the Arthropod/Nematoda or Mollusca/Annelida were not analyzed by this method and are arbitrarily shown in this figure

divergence of Agnatha but before the divergence of Chondrichthyes. Although this point is still to be confirmed by a genome analysis of species of these groups, it is possible that the drastic changes in the complement system occurred simultaneously with the appearance of adaptive immunity.

The urochordate genome analysis performed on Ciona intestinalis has demonstrated that most complement gene families are present in Urochordata and many of them have multiple members (Azumi et al. 2003). However, these multiple members do not show a one-to-one orthologous relationship with members of the same gene family in higher vertebrates, indicating that the gene duplications among members of each gene family occurred independently in Urochordata and Vertebrata. No complement gene sequence from Hemichordata was reported and only fragmental information is available from Cephalochordata and Echinodermata. However, ongoing amphioxus and sea 


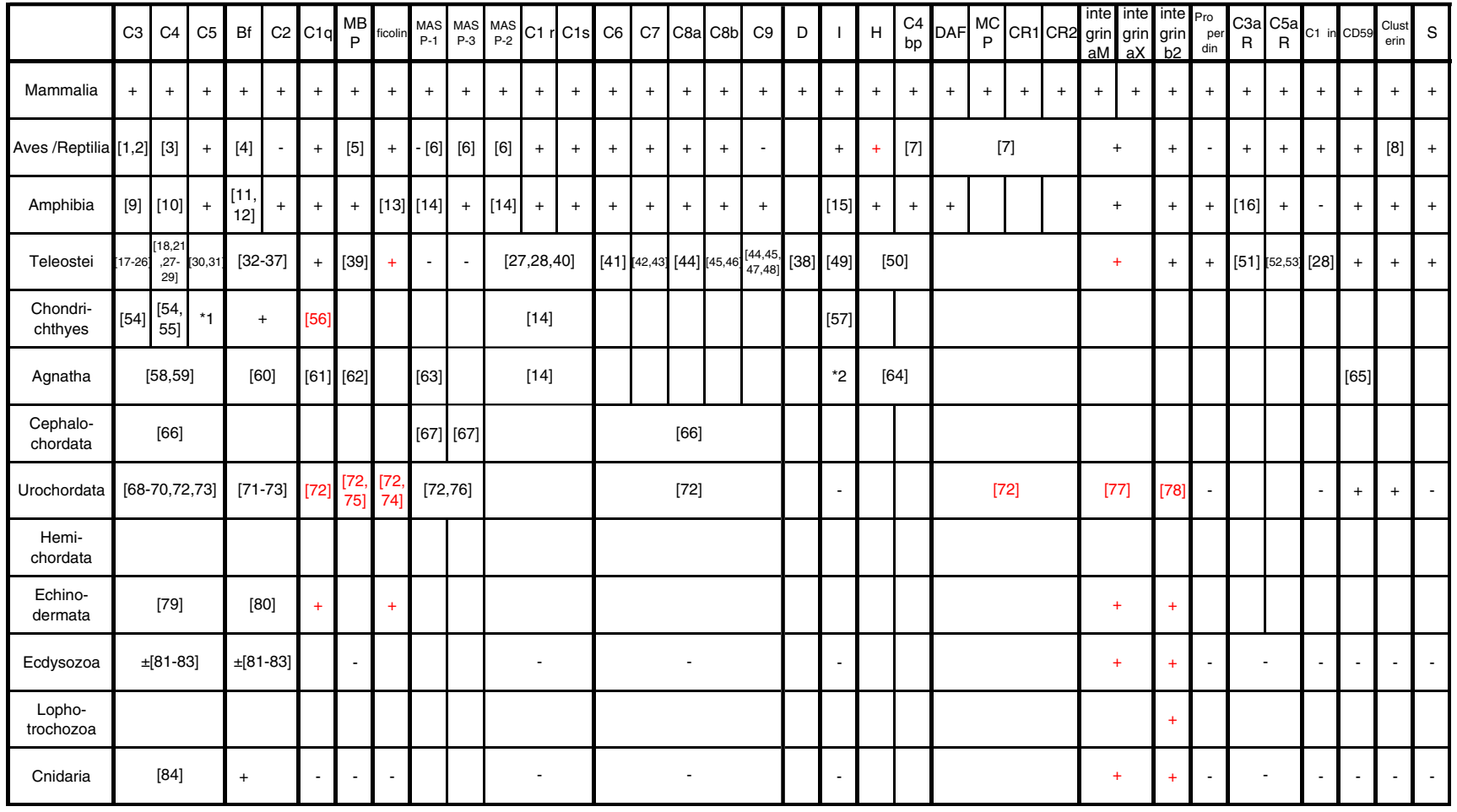

Fig. 2 Presence or absence of complement component genes in various animal groups. All complement components and related genes of human, as a representative of Mammalia, are shown, and the presence of the orthologous genes reported from the other animal groups are indicated by the reference numbers. Plus and minus indicate the presence and absence, respectively, of the orthologous genes in the assembled genome sequences of at least one representative species of each group. Genes located outside of the complement gene clusters in the phylogenetic tree, showing an uncertain orthologous relationship with complement genes, are indicated in red. Literatures cited here are: 1 Mavroidis et al. 1995; 2 Fritzinger et al. 1992; 3 Kaufman et al. 1999; 4 Kjalke et al. 1993; 5 Laursen et al. 1998; 6 Lynch et al. 2005; 7 Oshiumi et al. 2005; 8 Mahon et al. 1999; 9 Grossberger et al. $1989 ; 10$ Mo et al. 1996; 11 Kato et al. $1995 ; 12$ Kato et al. 1994; 13 Endo et al. 1998 and Kakinuma et al. 2003; 14 Endo et al. 1998; 15 Kunnath-Muglia et al. 1993; 16 Boshra et al. 2005; 17 Abelseth et al. 2003; 18 Samonte et al. 2002; 19 Zarkadis et al. 2001; 20 Nakao et al. 2000; 21 Kuroda et al. 2000; 22 Sato et al. 1999; 23 Sunyer et al. 1997b; 24 Sunyer et al. 1997a; 25 Sunyer et al. 1996; 26 Lambris et al. 1993; 27 Boshra et al. 2004a; 28 Wang and Secombes 2003; 29 Sambrook et al. 2003; 30 Kato et al. 2003; 31

urchin genome projects should reveal the early evolution of the deuterostome complement system.

Because the protostome genomes analyzed first in $D$. melanogaster and C. elegans contained no complement genes, the complement system was believed to be a unique property of deuterostomes. However, the recent identification of some complement genes from horseshoe crab (Zhu et al. 2005) and Cnidaria (Dishaw et al. 2005) has indicated that the origin of the complement system is extremely ancient. Therefore, the absence of the complement genes in D. melanogaster and $C$. elegans seems to be due to secondary loss. These two model animals have a very short generation time, and it is tempting
Franchini et al. 2001; 32 Nakao et al. 2002; 33 Sunyer et al. 1998; 34 Nakao et al. 1998; 35 Gongora et al. 1998; 36 Seeger et al. 1996; 37 Kuroda et al. 1996; 38 Yano and Nakao 1994; 39 Vitved et al. 2000; 40 Nakao et al. 2001; 41 Chondrou et al. 2006; 42 Zarkadis et al. 2005; 43 Papanastasiou and Zarkadis 2005; 44 Uemura et al. 1996; 45 Katagiri et al. 1999; 46 Kazantzi et al. 2003; 47 Yeo et al. 1997; 48 Tomlinson et al. 1993; 49 Nakao et al. 2003a; 50 Kemper et al. 1998; 51 Boshra et al. 2005; 52 Boshra et al. 2004b; 53 Fujiki et al. 2003; 54 Dodds et al. 1998; 55 Terado et al. 2003; 56 Smith 1998; 57 Terado et al. 2002; 58 Ishiguro et al. 1992; 59 Nonaka et al. 1984 and Nonaka and Takahashi 1992; 60 Nonaka et al. 1994; 61 Matsushita et al. 2004; 62 Takahashi et al. 2006; 63 Song et al. 2005; 64 Kimura et al. 2004; 65 dos Remedios et al. 1999; 66 Suzuki et al. 2002; 67 Endo et al. 2003; 68 Raftos et al. 2002; 69 Marino et al. 2002; 70 Nonaka et al. 1999; 71 Yoshizaki et al. 2005; 72 Azumi et al. 2003; 73 Dehal et al. 2002; 74 Kenjo et al. 2001; 75 Sekine et al. 2001; 76 Ji et al. 1997; 77 Miyazawa and Nonaka 2004; 78 Miyazawa et al. 2001; 79 Al-Sharif et al. 1998; 80 Smith et al. 1998; 81 Zhu et al. 2005; 82 Adams et al. 2000; 83 The C. elegans Sequencing Consortium 1998; 84 Dishaw et al. $2005 ; * 1$ H. Nagumo et al., unpublished data; and $* 2$ A. Kimura and $\mathrm{M}$. Nonaka, unpublished data

to speculate that their genomes were streamlined, thus getting rid of the complement genes.

The sea anemone ( $N$. vectensis) genome contained only the two complement genes, $\mathrm{C} 3$ and $\mathrm{Bf}$. This result suggests that the sea anemone complement system is simple, composed of only two central components. However, we cannot rule out the possibility that other complement genes are present in sea anemone, but their sequences are much too diverged to be detected by Basic Local Alignment Search Tool (BLAST).

In the following sections, we discuss the individual evolution of each complement gene family. 


\section{$\mathrm{C} 3 / \mathrm{C} 4 / \mathrm{C} 5$}

In contrast to the other complement components, C3, C4, and $\mathrm{C} 5$ were considered to be unique in that they do not have an obvious domain structure. Recent elucidation of the crystal structure of C3 (Janssen et al. 2005), however, has revealed that human $\mathrm{C} 3$ is composed of 13 domains: eight macroglobulin domains, a linker domain, an anaphylatoxin domain, a CUB domain, a thioester-containing domain, and a C345C domain. Although steric structures of the eight macroglobulin domains are similar to each other, there is almost no similarity in their amino acid sequences, explaining why this repeating structure had not been recognized until the crystal structure was elucidated. The primary structures of complement components $\mathrm{C} 3, \mathrm{C} 4$, and $\mathrm{C} 5$ show a weak but significant similarity to those of a serum protease inhibitor alpha2-macroglobulin (A2M) and a glycosylphosphatidylinositol-anchored cell surface molecule CD109 (Solomon et al. 2004; Sottrup-Jensen et al. 1985). Moreover, they share a unique structure, an intramolecular thioester bond, except for C5, which is believed to have lost it secondarily. Therefore, the family composed of these genes is called the thioester-containing protein (TEP) gene family. Elucidation of the domain structure of $\mathrm{C} 3$ has suggested that the ancestral molecule of the TEP proteins has a simple repeating structure composed of eight macroglobulin domains, and that the other domains were inserted later.

An increasing number of TEP family genes are being identified from various animal phyla, making it clearer that this family is divided into two subfamilies: the C3 subfamily comprising $\mathrm{C} 3, \mathrm{C} 4$, and $\mathrm{C} 5$ and the $\mathrm{A} 2 \mathrm{M}$ subfamily comprising A2M, CD109, and insect TEP. Because only the latter subfamily members were identified in the genomes of D. melanogaster and C. elegans, whereas both subfamily members were identified from all analyzed deuterostomes, the $\mathrm{C} 3$ subfamily was considered to be established by gene duplication from $\mathrm{A} 2 \mathrm{M}$ in the deuterostome lineage (Nonaka 2001). However, recent identification of the $\mathrm{C} 3$ subfamily members in arthropodian horseshoe crab (Zhu et al. 2005) and cnidarian coral (Dishaw et al. 2005) has indicated that the origin of the $\mathrm{C} 3$ gene is traced back to before the divergence of Cnidaria and Bilateralia, and is estimated to be about 1,300 MYA. Moreover, the members of both $\mathrm{C} 3$ and $\mathrm{A} 2 \mathrm{M}$ subfamilies are present in the nematostella genome ( $N$. vectensis, http:// www.stellabase.org/). Thus, the emergence of the TEP molecules and TEP differentiation into the $\mathrm{C} 3$ and $\mathrm{A} 2 \mathrm{M}$ subfamilies seems to have predated the divergence of Cnidaria and Bilateralia. Although the evolutionary origin of the TEP gene is still to be clarified, our preliminary reverse transcriptase polymerase chain reaction search for the TEP genes in species of sponges failed (S. Sugimoto and M. Nonaka, unpublished data). The presence of TEP family genes in prokaryotes was reported (Budd et al. 2004). However, the distribution of TEP genes in various bacteria does not fit with their phylogeny, leading the authors to conclude that they were obtained secondarily by a horizontal gene transfer from eukaryotes.

At least one A2M subfamily member was identified from all eumetazoa searched for TEP genes, although the C3 subfamily member was identified only from deuterostomes, a protostome, horseshoe crab, and cnidarians. Thus, the $\mathrm{C} 3$ gene that appeared before the Cnidaria/Bilateralia divergence seems to have been lost many times at various stages during the protostome evolution. In the deuterostome lineage, the $\mathrm{C} 3$ gene multiplied independently at least twice in the urochordate and vertebrate lineages. In the vertebrate lineage, the $\mathrm{C} 3$ multiplication that gave rise to $\mathrm{C} 3, \mathrm{C} 4$, and C5 occurred before the emergence of cartilaginous fish because all three genes are present in sharks (Terado et al. 2003; H. Nagumo et al, unpublished data). In contrast, it is not clear whether this multiplication occurred before or after the divergence of Agnatha; upon phylogenetic tree analysis the agnathan genes isolated from lamprey (Nonaka and Takahashi 1992) and hagfish (Ishiguro et al. 1992) were located in the $\mathrm{C} 3$ clade rather than outside of the $\mathrm{C} 3$ / $\mathrm{C} 4 / \mathrm{C} 5$ cluster, although no additional member of this gene family was identified from Agnatha.

\section{Bf/C2}

The domain structure of this family gene, composed of three SCR domains, a von Willebrand factor type A domain and a serine protease domain, is unique among the higher vertebrate genes. Thus, there is no doubt that the genes with essentially the same domain structure found in horseshoe crab and sea anemone are orthologs of the mammalian $\mathrm{Bf}$ and $\mathrm{C} 2$, indicating that the origin of this gene family is more ancient than the divergence of Cnidaria and Bilateralia. From all the deuterostomes analyzed so far, at least one member of this family was identified. In some cases, extra domains were added at the $\mathrm{N}$ terminus: the ascidian Bf has extra SCR and low-density lipoprotein receptor (LDLR) domains (Yoshizaki et al. 2005), and the sea urchin $\mathrm{Bf}$ has an extra SCR domain (Smith et al. 1998). The presence of both $\mathrm{Bf}$ and $\mathrm{C} 2$ was reported in amphibia (Ohta et al. 2006) and mammals, indicating that the $\mathrm{Bf} / \mathrm{C} 2$ gene duplication predated the amphibia/mammal divergence. On the other hand, lamprey (Nonaka et al. 1994) and invertebrate Bf (Smith et al. 1998; Yoshizaki et al. 2005) are located outside of the jawed vertebrate $\mathrm{Bf}$ and $\mathrm{C} 2$ in the phylogenetic tree, suggesting that the $\mathrm{Bf} / \mathrm{C} 2$ gene duplication occurred in the jawed vertebrate lineage. However, the $\mathrm{Bf} / \mathrm{C} 2$ genes of the bony and cartilaginous fish (Kuroda et 
al. 1996; Nakao et al. 1998; Seeger et al. 1996; Terado et al. 2001) show almost the same degree of similarity to the tetrapod $\mathrm{Bf}$ and $\mathrm{C} 2$ genes, making it difficult to further define the timing of the $\mathrm{Bf} / \mathrm{C} 2$ gene duplication.

\section{C1q/MBP/ficolin}

All these molecules have the collagen domain at their $\mathrm{N}$ terminus. In contrast, they have their respective globular domains at their $\mathrm{C}$ terminus. The overall domain structure of these molecules is relatively simple, composed of only two domains. In addition, these domain structures are shared not only by the complement components but also by a number of noncomplement proteins in mammals. Thus, phylogenetic tree analyses are required to assess the orthologous relationships between the mammalian and nonmammalian genes. The phylogenetic tree analysis of the $\mathrm{Clq}$ and related genes has indicated that the lamprey $\mathrm{C} 1 \mathrm{q}$ gene forms a clade with the higher vertebrate $\mathrm{C} 1 \mathrm{qA}$, $\mathrm{C} 1 \mathrm{qB}$, and $\mathrm{C} 1 \mathrm{qC}$ genes (Matsushita et al. 2004). In contrast, the sea urchin and ascidian Clq-like genes are located outside of this clade together with the related mammalian and fish genes. These results indicate that $\mathrm{C} 1 \mathrm{q}$ most probably emerged at an early stage of vertebrate evolution before the establishment of adaptive immunity and the emergence of immunoglobulin. Thus, original $\mathrm{C} 1 \mathrm{q}$ seems to have recognized foreign molecules independent from immunoglobulins.

The lamprey mannan-binding protein (MBP) genes were reported recently (Takahashi et al. 2006). Together with the previous reports on MBP of mammals, birds, and teleosts, this report indicates that the origin of MBP can be traced back to an early stage of vertebrate evolution. However, mammalian and bird lung surfactant protein genes, SP-A and SP-D, seem to have diverged from MBP after the divergence of Agnatha. Ascidian glucose-binding lectin and MBPs are located outside of the vertebrate MBP, surfactant protein, and other collectin clusters, thus rendering the orthologous relationship between the vertebrate and ascidian MBP genes to be doubtful.

In contrast to $\mathrm{C} 1 \mathrm{q}$ and $\mathrm{MBP}$, ficolin orthologs have so far been identified only from tetrapods. In the phylogenetic tree, genes with the same domain structure reported in the teleost, ascidian, and sea urchin are grouped together with nonficolin genes of higher vertebrates. Thus, the origin of ficolin seems to be much younger than that of $\mathrm{C} 1 \mathrm{q}$ or MBP.

\section{MASP-1, MASP-2, MASP-3, C1r, and C1s}

The evolution of this gene family was reviewed several times because of its unique and interesting processes, including gene duplication, retrotransposition, and modification of the serine protease-encoding regions (Fujita 2002; Fujita et al. 2004; Nonaka and Miyazawa 2002; Nonaka and Yoshizaki 2004). Therefore, we discuss here only one of this gene family's major evolutionary events: the origin of the apparently modern MASP-2, MASP-3, C1r, and C1s genes. From the structural comparison of the mammalian and various chordate MASP-1, MASP-3, MASP-2, C1r, and $\mathrm{C} 1 \mathrm{~s}$ genes, it is suggested that the ancestral MASP-2, MASP-3, C1r, and C1s genes were generated by the insertion of a new serine protease-encoding exon into an ancient MASP-1 gene. Only the MASP-1 type genes are present in ascidians, and both the MASP-1 type and MASP-2, MASP-3, C1r, and C1s type genes are present in amphioxus. Based on the previous understanding of animal phylogeny that cephalochordates and vertebrates are more closely related to each other than either is to urochordates, this result seemed to suggest that the retrotransposition to generate the MASP-2, MASP-3, C1r, and $\mathrm{C} 1 \mathrm{~s}$ type genes occurred after the divergence of urochordates but before the divergence of cephalochordates in the lineage leading to vertebrates. However, following upon the revision of chordate evolution, a new interpretation is that this retrotransposition occurred in the common ancestor of chordates, and urochordates secondarily lost the MASP-2, MASP-3, C1r, and C1s type genes. Similarly, loss of the MASP-1 type gene also occurred multiple times because lamprey, shark, carp, and chicken seem to have only the MASP-2, MASP-3, C1r, and C1s type genes. The evolutionary origin of the $\mathrm{C} 1 \mathrm{r}$ and $\mathrm{C} 1 \mathrm{~s}$ genes remains to be clarified, although the presence of functional evidence in shark (Jensen et al. 1981) and functional and molecular evidence in carp (Nakao et al. 2003b) suggest that the $\mathrm{C} 1 \mathrm{r}$ and $\mathrm{Cls}$ genes were established in the common ancestor of the jawed vertebrates.

\section{Terminal components}

The terminal complement components (TCCs) and $\mathrm{C} 5 \mathrm{~b}$ assemble to form the membrane attack complex (MAC), which forms pores on the plasma membrane of the target cell, disturbs the membrane potential, and finally leads to cell lysis. Mammalian TCCs, C6, C7, C8A, C8B, and C9 share a unique domain structure, composed of the TSP (thrombospondin type I) domain, the LDLR class A domain, the membrane attack complex/perforin (MACPF) domain, and the epidermal growth factor (EGF)-like domain, while C6 and C7 have additional domains: the complement control protein $(\mathrm{CCP})$ domain and the factor $\mathrm{I} /$ membrane attack complex (FIM) domain at their C termini. All TCC genes are present in the mammalian, avian, and amphibian genomic sequences, except for the avian $\mathrm{C} 9$ gene, which is not found 
in the draft genome sequence of chicken (Fig. 2). Although the origin of the TCC genes can be traced back to before the divergence of urochordates, cephalochordates, and vertebrates, the gene duplications among the $\mathrm{C} 6, \mathrm{C} 7, \mathrm{C} 8$, and $\mathrm{C} 9$ genes seem to have occurred in the vertebrate lineage after its divergence from urochordates and cephalochordates. It is interesting to note that it is possible that primitive ascidian and amphioxus TCCs are not activated through the complement system because they lack the FIM domain responsible for the interaction with the $\mathrm{C} 345 \mathrm{C}$ domain of C5 (Thai and Ogata 2004) and the CCP domain, which potentially interact with other complement molecules. Thus, although the orthologous relationship between ascidian/amphioxus TCCs and mammalian TCCs is well supported by their domain structures, the biological function and activation mechanism of ascidian and amphioxus TCCs could be quite different. Despite an earlier report on the presence of the TCC in sharks, no gene sequence was published to date. In addition, there is no information at all on the TCC of cyclostomes. Identification and structural characterization of the TCC genes in these animals will clarify the evolution of the TCC genes involved in the MAC formation.

On the other hand, proteins containing the MACPF domain, but lacking the other TCC-specific domains, are found in many organisms belonging to the broad range of phyla and even kingdoms, though many of them are merely predicted genes from the draft genomes and have no known function. They include (1) invertebrates: sea urchin (Haag et al. 1999), abalones (Mah et al. 2004), venomous sea anemone (Nagai et al. 2002; Oshiro et al. 2004), and Drosophila melanogaster (Martin et al. 1994); (2) protozoans: malarial parasite Plasmodium (Kaiser et al. 2004), bovine parasite Theileria annulata, and Tetrahymena thermophila; (3) plants: Arabidopsis thaliana (MoritaYamamuro et al. 2005) and Oryza sativa; (4) (pathogenic) fungi: Emericella nidulans; (5) bacteria: Chlamydias (Ponting 1999), luminescent bacterium, and intraintestinal bacterium.

Some of these MACPF domain-containing molecules are known to have a toxic function or are implicated in pathogenesis or developmental pathways. In addition, astrotactin proteins of vertebrates composed of one MACPF, one fibronectin type 3, and three EGF-like domains are implicated in neuronal migration along glial fibers (Zheng et al. 1996). Among these, non-TCC MACPF molecules, toxins of the venomous sea anemone possessing the MACPF and EGF domains and a very high hemolytic potential, are possibly closest to the TCCs. However, the mechanism to avoid host damage is quite different; the hemolytic toxins of sea anemone are enclosed in the nematocyst and are released only upon stinging the target body, while the TCCs are serum proteins whose hemolytic activity is regulated by interactions with the complement system through the additional TCC-specific domains.

Taken together, in the common ancestor of chordates TCC molecules seem to have been tuned for extremely effective, targeted, and regulated hemolytic function by the addition of the extra domains to the MACPF domain.

\section{Other complement components}

As shown in Fig. 2, most of the other component genes are present in the teleost genomes but not in the ascidian genome, suggesting that either these genes emerged in the vertebrate lineage or that they are evolving too quickly, making it difficult to detect the ascidian counterparts by BLAST search using vertebrate sequences as the query. The absence of genome-wide information in cartilaginous fish and agnatha prevents a further definition of the evolutionary origin of these genes. For the complement regulators or receptors with the SCR domains, RCA, the structural and functional counterpart was reported from lamprey (Kimura et al. 2004), although the biological function of the structural orthologs in ascidians is yet to be clarified (Azumi et al. 2003). For the CR3 and CR4 genes, which encode integrin complement receptors composed of the alpha and beta chains, the presence of the structural orthologs is confirmed in the draft genome of X. tropicalis, although four copies of the alpha genes show a similar level of similarity to CR3 and CR4. In contrast, ascidian genes, whose products were shown to play a role as a $\mathrm{C} 3$ receptor, did not show an orthologous relationship with the mammalian functional counterparts (Miyazawa et al. 2001; Miyazawa and Nonaka 2004). Both the alpha and beta chain genes seem to have expanded in the vertebrate lineage after the divergence of urochordates, suggesting that the functional and structural diversification of integrins occurred in the vertebrate lineage, although $\mathrm{C} 3$ was one of the original ligands.

\section{Evolutionarily conserved linkage}

The most curious genetic linkage among the mammalian complement genes may be that among the $\mathrm{C} 4, \mathrm{Bf}$, and $\mathrm{C} 2$ genes found in the MHC (Carroll et al. 1984; Chaplin et al. 1983). The $X$. tropicalis genome analysis has indicated that these genes are also tightly linked to each other in the frog MHC (Ohta et al. 2006). Although the $\mathrm{C} 4$ and $\mathrm{Bf} / \mathrm{C} 2$ genes are not linked to each other or to MHC class I or II genes in teleost (Kuroda et al. 1996, 2000; Samonte et al. 2002), this may be due to teleost-specific extensive genomic rearrangement, and the shark $\mathrm{C} 4$ and $\mathrm{Bf} / \mathrm{C} 2$ genes are linked to each other in its MHC (Terado et al. 2003). Thus, the basic 
genome structure of the MHC complement gene region seems to have been established early in the evolution of jawed vertebrates. Using the entire genome information on an ascidian urochordate, $C$. intestinalis, the possibility was analyzed that the origin of this linkage was more ancient and that the common ancestor of $\mathrm{C} 3, \mathrm{C} 4$, and $\mathrm{C} 5$ and the common ancestor of $\mathrm{Bf}$ and $\mathrm{C} 2$ were linked to each other before the establishment of the MHC. C. intestinalis has two $\mathrm{C} 3$ genes on two different chromosomes and three $\mathrm{Bf}$ genes arranged in tandem on another chromosome (Yoshizaki et al. 2005). Thus, it is likely that the linkage between the $\mathrm{C} 4$ and $\mathrm{Bf} / \mathrm{C} 2$ genes was simultaneously established in the jawed vertebrate lineage with the establishment of the classical pathway or the adaptive immune system. It is tempting to speculate that the close linkage between these complement genes played some role in establishing the classical pathway by promoting coevolution of these genes. Because the gene duplication that gave rise to $\mathrm{Bf}$ and $\mathrm{C} 2$ genes was most probably a tandem type, the $\mathrm{Bf} / \mathrm{C} 2$ and $\mathrm{C} 3 / \mathrm{C} 4 / \mathrm{C} 5$ gene duplications are considered to be independent events. It is likely that these duplications occurred in the vertebrate lineage after the divergence of cyclostomes but before the divergence of cartilaginous fish, and then the linkages between one of the duplicated $\mathrm{C} 3 / \mathrm{C} 4 / \mathrm{C} 5$ genes, the $\mathrm{Bf}$ and $\mathrm{C} 2$ genes, and between these genes and the MHC class I and II genes were established before the emergence of cartilaginous fish. Because the MHC was established just before the divergence of cartilaginous fish and higher vertebrates (Flajnik and Kasahara 2001), the C4, Bf, and C2 genes seem to be original members of the MHC.

Another curious linkage among the mammalian complement genes involves the RCA genes (Hourcade et al. 1992). The human RCA genes, composed of the SCR domains, are tightly clustered on the long arm of chromosome 1, at 1q32, suggesting that they were generated by recurrent tandem duplications. Similar clustering of the RCA genes is also found in chicken (Oshiumi et al. 2005) and frog, although the latter contains only two genes. No clear linkage

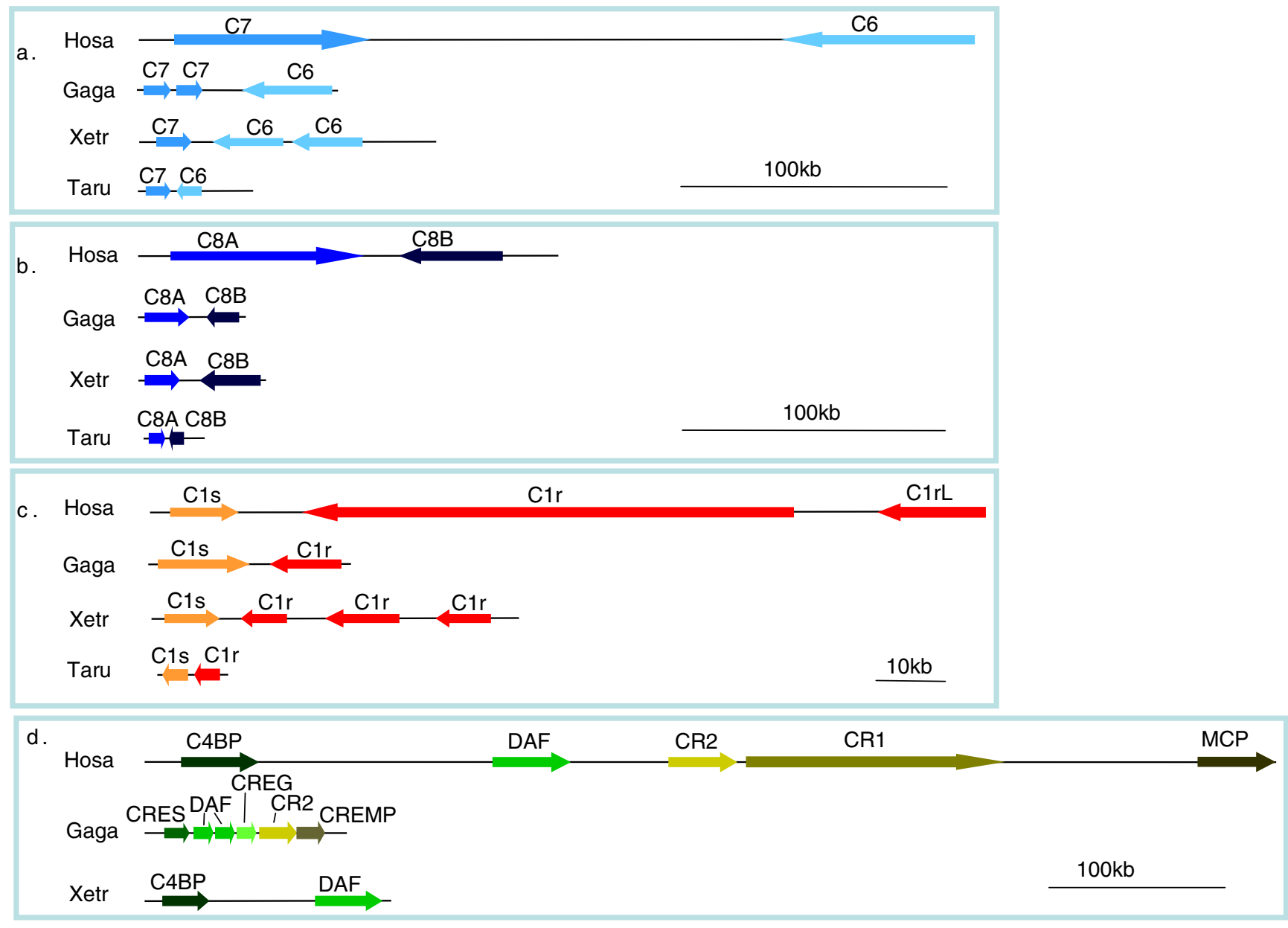

Fig. 3 Evolutionary conservation of genetic linkages between complement genes. Genomic organization of four sets of the linked complement genes in four species, human (Hosa), chicken (Gaga), clawed frog (Xetr), and fugu (Taru), are shown to scale: a C6 and C7, b $\mathrm{C} 8 \mathrm{~A}$ and $\mathrm{C} 8 \mathrm{~B}, \mathbf{c} \mathrm{C} 1 \mathrm{r}$ and $\mathrm{C} 1 \mathrm{~s}$, and $\mathbf{d} \mathrm{RCA}$ genes. Note that the relative orientations of these genes are perfectly conserved except for the fish $\mathrm{C} 1 \mathrm{~s}$ gene 
between the SCR genes was observed in the fugu genome. The RCA genes display a rapid evolution in both the primary structure and the number of SCR domains, and it is not easy to determine the orthologous relationships between the genes from different animal classes. Even between human and mouse, the counterparts of certain genes are missing from the other species. Despite the difficulty in lineage identification of the RCA genes, it is conceivable that at least one round of tandem duplication predated the emergence of amphibia because $X$. tropicalis has linked C4BP and DAF genes. These two genes are considered to be the founding members of the vertebrate RCA gene cluster.

The other linkages between the complement genes recognized in the mammalian genome are those between $\mathrm{C} 6$ and $\mathrm{C} 7, \mathrm{C} 8 \mathrm{~A}$ and $\mathrm{C} 8 \mathrm{~B}$, and $\mathrm{C} 1 \mathrm{r}$ and $\mathrm{C} 1 \mathrm{~s}$. All of these linkages are conserved in the chicken, frog, and fugu genomes, and only a few tandem duplications (Hosa C1r, Xetr C1r, Gaga C7, and Xetr C6) and one inversion (Taru C1s) are observed (Fig. 3). A high degree of conservation of these linkages, even in teleosts believed to have experienced an extensive genome rearrangement, suggests

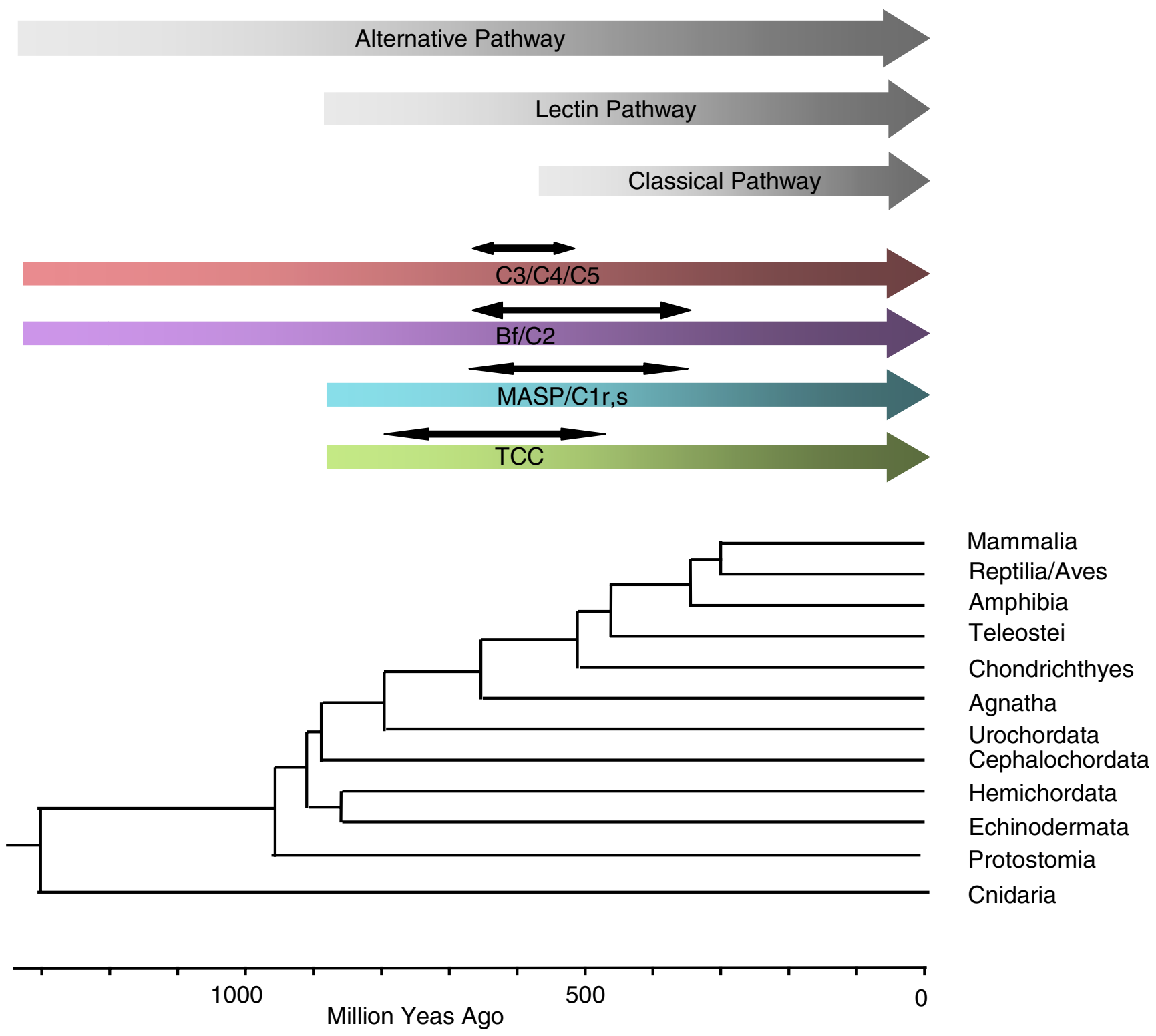

Fig. 4 Evolutionary processes of the complement system. Evolutionary origins of the three complement activation pathways are shown by the gray arrows. The origin and evolution of the major gene families of the complement system are shown by the colored arrows. Timings of the gene duplications that possibly contributed to the establishment of the classical pathway are shown by the double-headed arrows. Because the presence of the classical pathway was functionally demonstrated in sharks, it is likely that the $\mathrm{Bf} / \mathrm{C} 2$ and MASP/C1r,s gene duplication occurred before the emergence of cartilaginous fish 
the presence of selective pressure to keep them together, most probably facilitating the coevolution of the linked genes. It is interesting to note that the sizes of the genes and the intergenic regions showed species-specific variation almost proportional to their genome sizes, despite a high degree of conservation of the basic gene organization.

\section{Conclusion}

The current view of the complement system evolutionary processes is summarized in Fig. 4. First, the primitive complement system, most likely composed of $\mathrm{C} 3$ and $\mathrm{Bf}$ and thus similar to the mammalian alternative pathway, emerged in the common ancestor of Cnidaria and Bilateralia more than 1,300 MYA. Structural features of these Cnidaria genes suggest that the ancestral $\mathrm{C} 3$ was proteolytically activated by Bf, and that it formed a covalent bond with nonself molecules using its intramolecular thioester bond. Whereas the $\mathrm{C} 3$ and $\mathrm{Bf}$ genes were retained by deuterostomes, they were lost many times independently in the protostome lineages. Second, with the emergence of chordates (900 MYA), the MASP, MBL, and ficolin genes were recruited to the complement system, establishing the lectin pathway. Finally, vertebrate-specific complement gene duplications, such as those among $\mathrm{C} 3 / \mathrm{C} 4 / \mathrm{C} 5$ and between $\mathrm{Bf} / \mathrm{C} 2$ and $\mathrm{MASP} / \mathrm{C} 1 \mathrm{r} / \mathrm{s}$, occurred before the emergence of cartilaginous fish about 600 MYA, most probably contributing to the establishment of the third activation pathway, the classical pathway. Thus, the complement classical pathway seems to have been established simultaneously with the appearance of the lymphocyte-MHC-based adaptive immune system. Ancestral TCC genes appear to have been recruited by the complement system and duplicated to $\mathrm{C} 6 / \mathrm{C} 7 / \mathrm{C} 8 \mathrm{~A} / \mathrm{C} 8 \mathrm{~B} / \mathrm{C} 9$ before the appearance of the jawed vertebrates, although its timing still needs to be clarified in detail. The linkages between certain complement genes played a certain role in establishing the modern complement system by facilitating the coevolution of the linked genes.

\section{References}

Abelseth TK, Stensvag K, Espelid S, Nygaard R, Ellingsen T, Bogwald J, Dalmo RA (2003) The spotted wolffish (Anarhichas minor Olafsen) complement component C3: isolation, characterisation and tissue distribution. Fish Shellfish Immunol 15:13-27

Adams MD, Celniker SE, Holt RA, Evans CA, Gocayne JD, Amanatides PG, Scherer SE, Li PW, Hoskins RA, Galle RF, George RA, Lewis SE, Richards S, Ashburner M, Henderson SN, Sutton GG, Wortman JR, Yandell MD, Zhang Q, Chen LX, Brandon RC, Rogers YH, Blazej RG, Champe M, Pfeiffer BD, Wan KH, Doyle C, Baxter EG, Helt G, Nelson CR, Gabor Miklos GL, Abril JF, Agbayani A, An HJ, Andrews-Pfannkoch
C, Baldwin D, Ballew RM, Basu A, Baxendale J, Bayraktaroglu L, Beasley EM, Beeson KY, Benos PV, Berman BP, Bhandari D, Bolshakov S, Borkova D, Botchan MR, Bouck J, Brokstein P, Brottier P, Burtis KC, Busam DA, Butler H, Cadieu E, Center A, Chandra I, Cherry JM, Cawley S, Dahlke C, Davenport LB, Davies P, de Pablos B, Delcher A, Deng Z, Mays AD, Dew I, Dietz SM, Dodson K, Doup LE, Downes M, Dugan-Rocha S, Dunkov BC, Dunn P, Durbin KJ, Evangelista CC, Ferraz C, Ferriera S, Fleischmann W, Fosler C, Gabrielian AE, Garg NS, Gelbart WM, Glasser K, Glodek A, Gong F, Gorrell JH, Gu Z, Guan P, Harris M, Harris NL, Harvey D, Heiman TJ, Hernandez JR, Houck J, Hostin D, Houston KA, Howland TJ, Wei MH, Ibegwam C et al (2000) The genome sequence of Drosophila melanogaster. Science 287:2185-2195

Al-Sharif WZ, Sunyer JO, Lambris JD, Smith LC (1998) Sea urchin coelomocytes specifically express a homologue of the complement component C3. J Immunol 160:2983-2997

Azumi K, De Santis R, De Tomaso A, Rigoutsos I, Yoshizaki F, Pinto M, Marino A, Shida K, Ikeda M, Ikeda M, Arai M, Inoue $Y$, Shimizu T, Satoh N, Rokhsar D, Du Pasquier L, Kasahara M, Satake M, Nonaka M (2003) Genomic analysis of immunity in a Urochordate and the emergence of the vertebrate immune system: "waiting for Godot." Immunogenetics 55(8):570-581

Blair JE, Hedges SB (2005a) Molecular clocks do not support the Cambrian explosion. Mol Biol Evol 22:387-390

Blair JE, Hedges SB (2005b) Molecular phylogeny and divergence times of deuterostome animals. Mol Biol Evol 22:2275-2284

Boshra H, Gelman AE, Sunyer JO (2004a) Structural and functional characterization of complement $\mathrm{C} 4$ and $\mathrm{C} 1$ s-like molecules in teleost fish: insights into the evolution of classical and alternative pathways. J Immunol 173:349-359

Boshra H, Li J, Peters R, Hansen J, Matlapudi A, Sunyer JO (2004b) Cloning, expression, cellular distribution, and role in chemotaxis of a $\mathrm{C} 5$ a receptor in rainbow trout: the first identification of a $\mathrm{C} 5 \mathrm{a}$ receptor in a nonmammalian species. J Immunol $172: 4381-4390$

Boshra H, Wang T, Hove-Madsen L, Hansen J, Li J, Matlapudi A, Secombes CJ, Tort L, Sunyer JO (2005) Characterization of a C3a receptor in rainbow trout and Xenopus: the first identification of $\mathrm{C} 3 \mathrm{a}$ receptors in nonmammalian species. J Immunol $175: 2427-2437$

Budd A, Blandin S, Levashina EA, Gibson TJ (2004) Bacterial alpha2-macroglobulins: colonization factors acquired by horizontal gene transfer from the metazoan genome? Genome Biol $5: \mathrm{R} 38$

Carroll MC, Campbell RD, Bentley DR, Porter RR (1984) A molecular map of the human major histocompatibility complex class III region linking complement genes $\mathrm{C} 4, \mathrm{C} 2$ and factor $\mathrm{B}$. Nature 307:237-241

Chaplin DD, Woods DE, Whitehead AS, Goldberger G, Colten HR, Seidman JG (1983) Molecular map of the murine $S$ region. Proc Natl Acad Sci USA 80:6947-6951

Chondrou MP, Mastellos D, Zarkadis IK (2006) cDNA cloning and phylogenetic analysis of the sixth complement component in rainbow trout. Mol Immunol 43:1080-1087

Day NK, Gewurz H, Johannsen R, Finstad J, Good RA (1970) Complement and complement-like activity in lower vertebrates and invertebrates. J Exp Med 132:941-950

Dehal P, Satou Y, Campbell RK, Chapman J, Degnan B, De Tomaso A, Davidson B, Di Gregorio A, Gelpke M, Goodstein DM, Harafuji N, Hastings KE, Ho I, Hotta K, Huang W, Kawashima T, Lemaire P, Martinez D, Meinertzhagen IA, Necula S, Nonaka M, Putnam N, Rash S, Saiga H, Satake M, Terry A, Yamada L, Wang HG, Awazu S, Azumi K, Boore J, Branno M, Chin-Bow S, DeSantis R, Doyle S, Francino P, Keys DN, Haga S, Hayashi H, Hino K, Imai KS, Inaba K, Kano S, Kobayashi K, Kobayashi M, 
Lee BI, Makabe KW, Manohar C, Matassi G, Medina M, Mochizuki Y, Mount S, Morishita T, Miura S, Nakayama A, Nishizaka S, Nomoto H, Ohta F, Oishi K, Rigoutsos I, Sano M, Sasaki A, Sasakura Y, Shoguchi E, Shin-i T, Spagnuolo A, Stainier D, Suzuki MM, Tassy O, Takatori N, Tokuoka M, Yagi K, Yoshizaki F, Wada S, Zhang C, Hyatt PD, Larimer F, Detter C, Doggett N, Glavina T, Hawkins T, Richardson P, Lucas S, Kohara Y, Levine M, Satoh N, Rokhsar DS (2002) The draft genome of Ciona intestinalis: insights into chordate and vertebrate origins. Science 298:2157-2167

Delsuc F, Brinkmann H, Chourrout D, Philippe H (2006) Tunicates and not cephalochordates are the closest living relatives of vertebrates. Nature 439:965-968

Dishaw LJ, Smith SL, Bigger CH (2005) Characterization of a C3-like cDNA in a coral: phylogenetic implications. Immunogenetics 57:535-548

Dodds AW, Smith SL, Levine RP, Willis AC (1998) Isolation and initial characterisation of complement components $\mathrm{C} 3$ and $\mathrm{C} 4$ of the nurse shark and the channel catfish. Dev Comp Immunol 22:207-216

dos Remedios NJ, Ramsland PA, Hook JW, Raison RL (1999) Identification of a homologue of CD59 in a cyclostome: implications for the evolutionary development of the complement system. Dev Comp Immunol 23:1-14

Endo Y, Takahashi M, Nakao M, Saiga H, Sekine H, Matsushita M, Nonaka M, Fujita T (1998) Two lineages of mannose-binding lectin-associated serine protease (MASP) in vertebrates. J Immunol 161:4924-4930

Endo Y, Nonaka M, Saiga H, Kakinuma Y, Matsushita A, Takahashi M, Matsushita M, Fujita T (2003) Origin of mannose-binding lectin-associated serine protease (MASP)-1 and MASP-3 involved in the lectin complement pathway traced back to the invertebrate, amphioxus. J Immunol 170:4701-4707

Flajnik MF, Kasahara M (2001) Comparative genomics of the MHC: glimpses into the evolution of the adaptive immune system. Immunity 15:351-362

Franchini S, Zarkadis IK, Sfyroera G, Sahu A, Moore WT, Mastellos D, LaPatra SE, Lambris JD (2001) Cloning and purification of the rainbow trout fifth component of complement (C5). Dev Comp Immunol 25:419-430

Fritzinger DC, Petrella EC, Connelly MB, Bredehorst R, Vogel CW (1992) Primary structure of cobra complement component C3. J Immunol 149:3554-3562

Fujiki K, Liu L, Sundick RS, Dixon B (2003) Molecular cloning and characterization of rainbow trout (Oncorhynchus mykiss) C5a anaphylatoxin receptor. Immunogenetics 55:640-646

Fujita T (2002) Evolution of the lectin-complement pathway and its role in innate immunity. Nat Rev Immunol 2:346-353

Fujita T, Matsushita M, Endo Y (2004) The lectin-complement pathway-its role in innate immunity and evolution. Immunol Rev 198:185-202

Gigli I, Austen KF (1971) Phylogeny and function of the complement system. Annu Rev Microbiol 25:309-332

Gongora R, Figueroa F, Klein J (1998) Independent duplications of Bf and $\mathrm{C} 3$ complement genes in the zebrafish. Scand J Immunol 48:651-658

Grossberger D, Marcuz A, Du Pasquier L, Lambris JD (1989) Conservation of structural and functional domains in complement component $\mathrm{C} 3$ of Xenopus and mammals. Proc Natl Acad Sci USA 86:1323-1327

Haag ES, Sly BJ, Andrews ME, Raff RA (1999) Apextrin, a novel extracellular protein associated with larval ectoderm evolution in Heliocidaris erythrogramma. Dev Biol 211:77-87

Hall JL, Rowlands DT Jr, Nilsson UR (1972) Complement-unlike hemolytic activity in lobster hemolymph. J Immunol 109:816823
Hedges SB, Blair JE, Venturi ML, Shoe JL (2004) A molecular timescale of eukaryote evolution and the rise of complex multicellular life. BMC Evol Biol 4:2

Hourcade D, Holers VM, Atkinson JP (1989) The regulators of complement activation (RCA) gene cluster. Adv Immunol 45:381-416

Hourcade D, Garcia AD, Post TW, Taillon-Miller P, Holers VM, Wagner LM, Bora NS, Atkinson JP (1992) Analysis of the human regulators of complement activation (RCA) gene cluster with yeast artificial chromosomes (YACs). Genomics 12:289-300

Ishiguro H, Kobayashi K, Suzuki M, Titani K, Tomonaga S, Kurosawa Y (1992) Isolation of a hagfish gene that encodes a complement component. EMBO J 11:829-837

Janssen BJ, Huizinga EG, Raaijmakers HC, Roos A, Daha MR, Nilsson-Ekdahl K, Nilsson B, Gros P (2005) Structures of complement component $\mathrm{C} 3$ provide insights into the function and evolution of immunity. Nature 437:505-511

Jensen JA, Festa E, Smith DS, Cayer M (1981) The complement system of the nurse shark: hemolytic and comparative characteristics. Science 214:566-569

Ji X, Azumi K, Sasaki M, Nonaka M (1997) Ancient origin of the complement lectin pathway revealed by molecular cloning of mannan binding protein-associated serine protease from a urochordate, the Japanese ascidian, Halocynthia roretzi. Proc Natl Acad Sci USA 94:6340-6345

Kaiser K, Camargo N, Coppens I, Morrisey JM, Vaidya AB, Kappe SH (2004) A member of a conserved Plasmodium protein family with membrane-attack complex/perforin (MACPF)-like domains localizes to the micronemes of sporozoites. Mol Biochem Parasitol 133:15-26

Kakinuma Y, Endo Y, Takahashi M, Nakata M, Matsushita M, Takenoshita S, Fujita T (2003) Molecular cloning and characterization of novel ficolins from Xenopus laevis. Immunogenetics 55:29-37

Katagiri T, Hirono I, Aoki T (1999) Molecular analysis of complement component C8beta and C9 cDNAs of Japanese flounder, Paralichthys olivaceus. Immunogenetics 50:43-48

Kato Y, Salter-Cid L, Flajnik MF, Kasahara M, Namikawa C, Sasaki M, Nonaka M (1994) Isolation of the Xenopus complement factor B complementary DNA and linkage of the gene to the frog MHC. J Immunol 153:4546-4554

Kato Y, Salter-Cid L, Flajnik MF, Namikawa C, Sasaki M, Nonaka M (1995) Duplication of the MHC-linked Xenopus complement factor B gene. Immunogenetics 42:196-203

Kato Y, Nakao M, Mutsuro J, Zarkadis IK, Yano T (2003) The complement component $\mathrm{C} 5$ of the common carp (Cyprinus carpio): cDNA cloning of two distinct isotypes that differ in a functional site. Immunogenetics 54:807-815

Kaufman J, Jacob J, Shaw I, Walker B, Milne S, Beck S, Salomonsen $\mathrm{J}$ (1999) Gene organisation determines evolution of function in the chicken MHC. Immunol Rev 167:101-117

Kazantzi A, Sfyroera G, Holland MC, Lambris JD, Zarkadis IK (2003) Molecular cloning of the beta subunit of complement component eight of rainbow trout. Dev Comp Immunol 27:167-174

Kemper C, Zipfel PF, Gigli I (1998) The complement cofactor protein (SBP1) from the barred sand bass (Paralabrax nebulifer) mediates overlapping regulatory activities of both human $\mathrm{C} 4 \mathrm{~b}$ binding protein and factor H. J Biol Chem 273:19398-19404

Kenjo A, Takahashi M, Matsushita M, Endo Y, Nakata M, Mizuochi T, Fujita T (2001) Cloning and characterization of novel ficolins from the solitary ascidian, Halocynthia roretzi. J Biol Chem 276:19959-19965

Kimura Y, Inoue N, Fukui A, Oshiumi H, Matsumoto M, Nonaka M, Kuratani S, Fujita T, Seya T (2004) A short consensus repeat- 
containing complement regulatory protein of lamprey that participates in cleavage of lamprey complement 3. J Immunol 173:1118-1128

Kjalke M, Welinder KG, Koch C (1993) Structural analysis of chicken factor B-like protease and comparison with mammalian complement proteins factor B and C2. J Immunol 151:4147-4152

Kunnath-Muglia LM, Chang GH, Sim RB, Day AJ, Ezekowitz RA (1993) Characterization of Xenopus laevis complement factor I structure-conservation of modular structure except for an unusual insert not present in human factor I. Mol Immunol 30:1249-1256

Kuroda N, Wada H, Naruse K, Simada A, Shima A, Sasaki M, Nonaka M (1996) Molecular cloning and linkage analysis of the Japanese medaka fish complement $\mathrm{Bf} / \mathrm{C} 2$ gene. Immunogenetics 44:459-467

Kuroda N, Naruse K, Shima A, Nonaka M, Sasaki M (2000) Molecular cloning and linkage analysis of complement $\mathrm{C} 3$ and C4 genes of the Japanese medaka fish. Immunogenetics $51: 117-128$

Lambris JD, Lao Z, Pang J, Alsenz J (1993) Third component of trout complement. cDNA cloning and conservation of functional sites. J Immunol 151:6123-6134

Laursen SB, Dalgaard TS, Thiel S, Lim BL, Jensen TV, Juul-Madsen HR, Takahashi A, Hamana T, Kawakami M, Jensenius JC (1998) Cloning and sequencing of a cDNA encoding chicken mannanbinding lectin (MBL) and comparison with mammalian analogues. Immunology 93:421-430

Lynch NJ, Khan SU, Stover CM, Sandrini SM, Marston D, Presanis JS, Schwaeble WJ (2005) Composition of the lectin pathway of complement in Gallus gallus: absence of mannan-binding lectinassociated serine protease-1 in birds. J Immunol 174:4998-5006

Mah SA, Moy GW, Swanson WJ, Vacquier VD (2004) A perforin-like protein from a marine mollusk. Biochem Biophys Res Commun 316:468-475

Mahon MG, Lindstedt KA, Hermann M, Nimpf J, Schneider WJ (1999) Multiple involvement of clusterin in chicken ovarian follicle development. Binding to two oocyte-specific members of the low density lipoprotein receptor gene family. J Biol Chem 274:4036-4044

Marino R, Kimura Y, De Santis R, Lambris JD, Pinto MR (2002) Complement in urochordates: cloning and characterization of two C3-like genes in the ascidian Ciona intestinalis. Immunogenetics 53:1055-1064

Martin JR, Raibaud A, Ollo R (1994) Terminal pattern elements in Drosophila embryo induced by the torso-like protein. Nature 367:741-745

Matsushita M, Matsushita A, Endo Y, Nakata M, Kojima N, Mizuochi T, Fujita T (2004) Origin of the classical complement pathway: lamprey orthologue of mammalian $\mathrm{C} 1 \mathrm{q}$ acts as a lectin. Proc Natl Acad Sci USA 101:10127-10131

Mavroidis M, Sunyer JO, Lambris JD (1995) Isolation, primary structure, and evolution of the third component of chicken complement and evidence for a new member of the alpha 2macroglobulin family. J Immunol 154:2164-2174

Miyazawa S, Nonaka M (2004) Characterization of novel ascidian beta integrins as primitive complement receptor subunits. Immunogenetics 55:836-844

Miyazawa S, Azumi K, Nonaka M (2001) Cloning and characterization of integrin alpha subunits from the solitary ascidian, Halocynthia roretzi. J Immunol 166:1710-1715

Mo R, Kato Y, Nonaka M, Nakayama K, Takahashi M (1996) Fourth component of Xenopus laevis complement: cDNA cloning and linkage analysis of the frog MHC. Immunogenetics 43:360-369

Morita-Yamamuro C, Tsutsui T, Sato M, Yoshioka H, Tamaoki M, Ogawa D, Matsuura H, Yoshihara T, Ikeda A, Uyeda I, Yamaguchi J (2005) The Arabidopsis gene CAD1 controls programmed cell death in the plant immune system and encodes a protein containing a MACPF domain. Plant Cell Physiol 46:902-912

Nagai H, Oshiro N, Takuwa-Kuroda K, Iwanaga S, Nozaki M, Nakajima $T$ (2002) Novel proteinaceous toxins from the nematocyst venom of the Okinawan sea anemone Phyllodiscus semoni Kwietniewski. Biochem Biophys Res Commun 294:760-763

Nakao M, Fushitani Y, Fujiki K, Nonaka M, Yano T (1998) Two diverged complement factor $\mathrm{B} / \mathrm{C} 2$-like cDNA sequences from a teleost, the common carp (Cyprinus carpio). J Immunol $161: 4811-48118$

Nakao M, Mutsuro J, Obo R, Fujiki K, Nonaka M, Yano T (2000) Molecular cloning and protein analysis of divergent forms of the complement component $\mathrm{C} 3$ from a bony fish, the common carp (Cyprinus carpio): presence of variants lacking the catalytic histidine. Eur J Immunol 30:858-866

Nakao M, Osaka K, Kato Y, Fujiki K, Yano T (2001) Molecular cloning of the complement $(\mathrm{C} 1 \mathrm{r} / \mathrm{C} 1 \mathrm{~s} / \mathrm{MASP} 2$-like serine proteases from the common carp (Cyprinus carpio). Immunogenetics 52:255-263

Nakao M, Matsumoto M, Nakazawa M, Fujiki K, Yano T (2002) Diversity of complement factor $\mathrm{B} / \mathrm{C} 2$ in the common carp (Cyprinus carpio): three isotypes of $\mathrm{B} / \mathrm{C} 2-\mathrm{A}$ expressed in different tissues. Dev Comp Immunol 26:533-541

Nakao M, Hisamatsu S, Nakahara M, Kato Y, Smith SL, Yano T (2003a) Molecular cloning of the complement regulatory factor I isotypes from the common carp (Cyprinus carpio). Immunogenetics 54:801-806

Nakao M, Mutsuro J, Nakahara M, Kato Y, Yano T (2003b) Expansion of genes encoding complement components in bony fish: biological implications of the complement diversity. Dev Comp Immunol 27:749-762

Nonaka M (2001) Evolution of the complement system. Curr Opin Immunol 13:69-73

Nonaka M, Miyazawa S (2002) Evolution of the initiating enzymes of the complement system. Genome Biol 3:REVIEWS1001

Nonaka M, Takahashi M (1992) Complete complementary DNA sequence of the third component of complement of lamprey. Implication for the evolution of thioester containing proteins. J Immunol 148:3290-3295

Nonaka M, Yoshizaki F (2004) Primitive complement system of invertebrates. Immunol Rev 198:203-215

Nonaka M, Yamaguchi N, Natsuume-Sakai S, Takahashi M (1981) The complement system of rainbow trout (Salmo gairdneri). I. Identification of the serum lytic system homologous to mammalian complement. J Immunol 126:1489-1494

Nonaka M, Fujii T, Kaidoh T, Natsuume-Sakai S, Yamaguchi N, Takahashi M (1984) Purification of a lamprey complement protein homologous to the third component of the mammalian complement system. J Immunol 133:3242-3249

Nonaka M, Takahashi M, Sasaki M (1994) Molecular cloning of a lamprey homologue of the mammalian MHC class III gene, complement factor B. J Immunol 152:2263-2269

Nonaka M, Azumi K, Ji X, Namikawa-Yamada C, Sasaki M, Saiga H, Dodds AW, Sekine H, Homma MK, Matsushita M, Endo Y, Fujita T (1999) Opsonic complement component C3 in the solitary ascidian, Halocynthia roretzi. J Immunol 162:387-391

Ohta Y, Goetz W, Hossain MZ, Nonaka M, Flajnik MF (2006) Ancestral organization of the MHC revealed in the amphibian Xenopus. J Immunol 176:3674-3685

Oshiro N, Kobayashi C, Iwanaga S, Nozaki M, Namikoshi M, Spring J, Nagai H (2004) A new membrane-attack complex/perforin (MACPF) domain lethal toxin from the nematocyst venom of the Okinawan sea anemone Actineria villosa. Toxicon 43:225-228

Oshiumi H, Shida K, Goitsuka R, Kimura Y, Katoh J, Ohba S, Tamaki Y, Hattori T, Yamada N, Inoue N, Matsumoto M, Mizuno S, Seya 
$\mathrm{T}$ (2005) Regulator of complement activation (RCA) locus in chicken: identification of chicken RCA gene cluster and functional RCA proteins. J Immunol 175:1724-1734

Papanastasiou AD, Zarkadis IK (2005) Gene duplication of the seventh component of complement in rainbow trout. Immunogenetics 57:703-708

Ponting CP (1999) Chlamydial homologues of the MACPF (MAC/ perforin) domain. Curr Biol 9:R911-R913

Raftos DA, Nair SV, Robbins J, Newton RA, Peters R (2002) A complement component C3-like protein from the tunicate, Styela plicata. Dev Comp Immunol 26:307-312

Sambrook JG, Campbell RD, Elgar G (2003) Characterisation of a gene cluster in Fugu rubripes containing the complement component $\mathrm{C} 4$ gene. Gene 312:73-83

Samonte IE, Sato A, Mayer WE, Shintani S, Klein J (2002) Linkage relationships of genes coding for alpha2-macroglobulin, C3 and $\mathrm{C} 4$ in the zebrafish: implications for the evolution of the complement and Mhc systems. Scand J Immunol 56:344-352

Sato A, Sultmann H, Mayer WE, Figueroa F, Tichy H, Klein J (1999) cDNA sequence coding for the alpha'-chain of the third complement component in the African lungfish. Scand J Immunol 49:367-375

Seeger A, Mayer WE, Klein J (1996) A complement factor B-like cDNA clone from the zebrafish (Brachydanio rerio). Mol Immunol 33:511-520

Sekine H, Kenjo A, Azumi K, Ohi G, Takahashi M, Kasukawa R, Ichikawa N, Nakata M, Mizuochi T, Matsushita M, Endo Y, Fujita T (2001) An ancient lectin-dependent complement system in an ascidian: novel lectin isolated from the plasma of the solitary ascidian, Halocynthia roretzi. J Immunol 167:4504-4510

Smith SL (1998) Shark complement: an assessment. Immunol Rev 166:67-78

Smith LC, Shih CS, Dachenhausen SG (1998) Coelomocytes express $\mathrm{SpBf}$, a homologue of factor $\mathrm{B}$, the second component in the sea urchin complement system. J Immunol 161:6784-6793

Solomon KR, Sharma P, Chan M, Morrison PT, Finberg RW (2004) CD109 represents a novel branch of the alpha2-macroglobulin/ complement gene family. Gene 327:171-183

Song L, Takamune K, Sugawara Y, Fujii T (2005) cDNA cloning of a mannose-binding lectin-associated serine protease (MASP) gene from hagfish (Eptatretus burgeri). Zoolog Sci 22:897-904

Sottrup-Jensen L, Stepanik TM, Kristensen T, Lonblad PB, Jones CM, Wierzbicki DM, Magnusson S, Domdey H, Wetsel RA, Lundwall A et al (1985) Common evolutionary origin of alpha 2macroglobulin and complement components $\mathrm{C} 3$ and $\mathrm{C} 4$. Proc Natl Acad Sci USA 82:9-13

Sunyer JO, Zarkadis IK, Sahu A, Lambris JD (1996) Multiple forms of complement $\mathrm{C} 3$ in trout that differ in binding to complement activators. Proc Natl Acad Sci USA 93:8546-8551

Sunyer JO, Tort L, Lambris JD (1997a) Diversity of the third form of complement, C3, in fish: functional characterization of five forms of C3 in the diploid fish Sparus aurata. Biochem J 326(Pt 3):877-881

Sunyer JO, Tort L, Lambris JD (1997b) Structural C3 diversity in fish: characterization of five forms of C3 in the diploid fish Sparus aurata. J Immunol 158:2813-2821

Sunyer JO, Zarkadis I, Sarrias MR, Hansen JD, Lambris JD (1998) Cloning, structure, and function of two rainbow trout $\mathrm{Bf}$ molecules. J Immunol 161:4106-4114

Suzuki MM, Satoh N, Nonaka M (2002) C6-like and c3-like molecules from the cephalochordate, amphioxus, suggest a cytolytic complement system in invertebrates. J Mol Evol 54:671-679

Takahashi M, Iwaki D, Matsushita A, Nakata M, Matsushita M, Endo Y, Fujita T (2006) Cloning and characterization of mannose-binding lectin from lamprey (Agnathans). J Immunol 176:4861-4868
Terado T, Smith SL, Nakanishi T, Nonaka MI, Kimura H, Nonaka M (2001) Occurrence of structural specialization of the serine protease domain of complement factor B at the emergence of jawed vertebrates and adaptive immunity. Immunogenetics 53:250-254

Terado T, Nonaka MI, Nonaka M, Kimura H (2002) Conservation of the modular structure of complement factor I through vertebrate evolution. Dev Comp Immunol 26:403-413

Terado T, Okamura K, Ohta Y, Shin DH, Smith SL, Hashimoto K, Takemoto T, Nonaka MI, Kimura H, Flajnik MF, Nonaka M (2003) Molecular cloning of C4 gene and identification of the class III complement region in the shark MHC. J Immunol 171:2461-2466

Thai CT, Ogata RT (2004) Complement components C5 and C7: recombinant factor I modules of $\mathrm{C} 7$ bind to the $\mathrm{C} 345 \mathrm{C}$ domain of C5. J Immunol 173:4547-4552

The C. elegans Sequencing Consortium (1998) Genome sequence of the nematode C. elegans: a platform for investigating biology. Science 282:2012-2018

Tomlinson S, Stanley KK, Esser AF (1993) Domain structure, functional activity, and polymerization of trout complement protein C9. Dev Comp Immunol 17:67-76

Uemura T, Yano T, Shiraishi H, Nakao M (1996) Purification and characterization of the eighth and ninth components of carp complement. Mol Immunol 33:925-932

Vitved L, Holmskov U, Koch C, Teisner B, Hansen S, Skjodt K (2000) The homologue of mannose-binding lectin in the carp family Cyprinidae is expressed at high level in spleen, and the deduced primary structure predicts affinity for galactose. Immunogenetics 51:955-964

Volanakis JE (1998) Overview of the complement system. In: Volanakis JE, Frank MM (eds) The human complement system in health and disease. Marcel Dekker, New York, pp 9-32

Volanakis JE, Arlaud GJ (1998) Complement enzymes. In: Volanakis JE, Frank MM (eds) The human complement system in health and disease. Marcel Dekker, New York, pp 49-81

Walport MJ (2001a) Complement. First of two parts. N Engl J Med 344:1058-1066

Walport MJ (2001b) Complement. Second of two parts. N Engl J Med 344:1140-1144

Wang T, Secombes CJ (2003) Complete sequencing and expression of three complement components, $\mathrm{C} 1 \mathrm{r}, \mathrm{C} 4$ and $\mathrm{C} 1$ inhibitor, of the classical activation pathway of the complement system in rainbow trout Oncorhynchus mykiss. Immunogenetics 55:615-628

Yano T, Nakao M (1994) Isolation of a carp complement protein homologous to mammalian factor D. Mol Immunol 31:337-342

Yeo GS, Elgar G, Sandford R, Brenner S (1997) Cloning and sequencing of complement component $\mathrm{C} 9$ and its linkage to DOC-2 in the pufferfish Fugu rubripes. Gene 200:203-211

Yoshizaki FY, Ikawa S, Satake M, Satoh N, Nonaka M (2005) Structure and the evolutionary implication of the triplicated complement factor B genes of a urochordate ascidian, Ciona intestinalis. Immunogenetics 56(12):930-942

Zarkadis IK, Sarrias MR, Sfyroera G, Sunyer JO, Lambris JD (2001) Cloning and structure of three rainbow trout $\mathrm{C} 3$ molecules: a plausible explanation for their functional diversity. Dev Comp Immunol 25:11-24

Zarkadis IK, Duraj S, Chondrou M (2005) Molecular cloning of the seventh component of complement in rainbow trout. Dev Comp Immunol 29:95-102

Zheng C, Heintz N, Hatten ME (1996) CNS gene encoding astrotactin, which supports neuronal migration along glial fibers. Science 272:417-419

Zhu Y, Thangamani S, Ho B, Ding JL (2005) The ancient origin of the complement system. EMBO J 24:382-394 